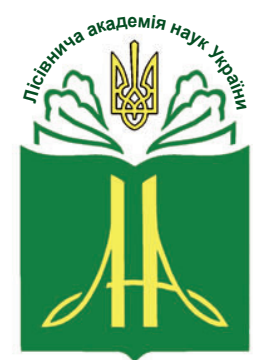

Forestry Academy of Sciences of Ukraine

Наукові праці Лісівничої академії наук України Proceedings of the Forestry Academy of Sciences of Ukraine

http://fasu.nltu.edu.ua https://doi.org/10.15421/412020

Article received 2019.11.18

Article accepted 2020.06.04
ISSN 1991-606X print

ISSN 2616-5015 online

(a) $\triangle$ Correspondence author Yuriy Huber

yuriy.huber@nltu.edu.ua

General Chuprynka st., 103, Lviv, 79057, Ukraine

УДК 674.048

\title{
Аналіз методів визначення тривалості сушіння соснових необрізних пиломатеріалів
}

\author{
Ю. М. Губер', 3. П. Копинець², Ю. Р. Дадак³, Ж. Я. Гуменюк
}

За результатами дослідних процесів сушіння, проведених у виробничих умовах у конвективній сушильній

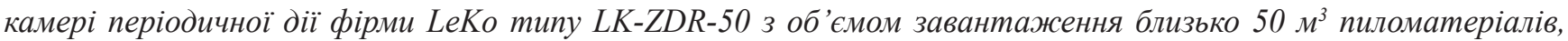
встановлено тривалість сушіння багатоступеневим режимом соснових необрізних пиломатеріалів завтовшки 30 мм та завдовжки 3.... 3,2 м. Під час виконання експериментальних досліджень початкова вологість пиломатеріалів становила $\mathrm{W}_{\mathrm{n}} \approx 45 \%$, кінцева $-\mathrm{W}_{\mathrm{k}} \approx 9 \%$. Температура агента сушіння (вологого повітря) на першому ступені режиму сушіня становила $\mathrm{t}_{\mathrm{c}}=52^{\circ} \mathrm{C}$, відносна вологість агента сушіння - $\varphi=73,5 \%$; на останньому ступені $-\mathrm{t}_{\mathrm{c}}=68^{\circ} \mathrm{C}, \varphi=32,5 \%$. Схема ииркуляиії агента сушіння в камері - поперечно-вертикальна, середня швидкість його руху через штабель за вологості висушуваних пиломатеріалів більше $31 \%-v=2,5 \mathrm{M} / \mathrm{c}$, за вологості менше $31 \%$ - v =1,5 $\mathrm{m} / \mathrm{c}$. Середнє значення тривалості досліджуваних процесів сушіння становить $\tau=146,28$ год.

Для аналізу обрано одинадиять розрахункових методів визначення тривалості сушіння пиломатеріалів.

Порівнюючи результати розрахунків тривалості сушіння з експериментальними даними встановлено, щзо для соснових необрізних пиломатеріалів у сучасних конвективних сушильних камерах періодичної дії можна рекомендувати такі методи: графоаналітичний П. С. Серговського - відхилення становить -2,32\%, аналітичний William T. Simpson - відхилення становить -7,25 \% та аналітичний L. Vorreiter - відхилення становить $-2,46 \%$.

3'ясовано, щзо метод згідно з T. Trübswetter матиме достатню для виробничих умов точність (відхилення становитиме -7,82\%) за умови внесення запропонованих у иій роботі поправок.

Ключові слова: параметри режиму сушіння; температура агента сушіння; відносна вологість; швидкість руху агента сушіння через штабель; конвективна сушильна камера періодичної діï.

\footnotetext{
Губер Юрій Мирославович - кандидат технічних наук, доцент кафедри технологій захисту навколишнього середовища і деревини, безпеки життєдіяльності та соціальних комунікацій. Національний лісотехнічний університет України, вул. генерала Чупринки, 103, м. Львів, 79057, Україна. Тел.: +38-067-811-71-18. E-mail: yuriy.huber@nltu.edu.ua ORCID: http://orcid.org/0000-0003-2678-511X

2 Копинець Зоя Павлівна - кандидат технічних наук, доцент кафедри технологій лісопиляння, столярних і дерев'яних будівельних виробів. Національний лісотехнічний університет України, вул. генерала Чупринки, 103, м. Львів, 79057, Україна. Тел.: +38-067-67020-58. E-mail: zoya.kopynets@nltu.edu.ua ORCID: http://orcid.org/0000-0001-8977-6953

3 Дадак Юрій Романович - кандидат технічних наук, доцент кафедри технологій лісопиляння, столярних і дерев'яних будівельних виробів. Національний лісотехнічний університет України, вул. генерала Чупринки, 103, м. Львів, 79057, Україна. Тел.: +38-067-22442-37. E-mail: yuriy.dadak@nltu.edu.ua ORCID: http://orcid.org/0000-0002-5423-0966

4 Гуменюк Жанна Ярославівна - асистент кафедри технологій захисту навколишнього середовища і деревини, безпеки життєдіяльності та соціальних комунікацій. Національний лісотехнічний університет України, вул. генерала Чупринки, 103, м. Львів, 79057, Україна. Тел.: +38-097-478-44-07. E-mail: zhanna.humenyuk@nltu.edu.ua ORCID: http://orcid.org/0000-0001-9453-5812
} 
Вступ. Процес сушіння пиломатеріалів $є$ одним iз ключових етапів виробництва, від якого суттєво залежить якість виробів 3 деревини. Тому йому приділяють значну увагу під час проектування нових деревообробних підприємств, їх розширення або реконструкції.

Сушіння пиломатеріалів у конвективних камерах періодичної дії $€$ найпоширенішим (Biley, Sokolovsky, Pavliust, \& Kunynets, 2010; Biley, 2005; Huber, 2003). Для забезпечення виконання виробничої програми важливим $€$ визначення кількості таких сушильних камер, під час розрахунку продуктивності яких враховується тривалість сушіння. Також встановлення тривалості сушіння $є$ важливим для планування роботи вже діючих сушильних цехів.

Робіт щодо порівняння різних методів визначення тривалості сушіння пиломатеріалів не так багато. Зокрема, Andreeva \& Petrovskaya (1970) порівнюють два графоаналітичні методи: П.С. Серговського та Е.А. Мікіта. У згаданому дослідженні розглянуто процеси конвективного сушіння соснових пиломатеріалів різних поперечних перетинів і за різних параметрів агента сушіння. Задовільною точністю розрахунків вважали відхилення розрахункових даних від експериментальних в межах $\pm 15 \%$, пояснюючи це анізотропією і мінливістю властивостей деревини. Відповідно до результатів, отриманих у цій роботі, точнішим виявився метод П.С. Сєрговського.

У роботі (Huber, \& Kopynets, 2009) для визначення тривалості сушіння дубових пиломатеріалів завтовшки 8 мм і завширшки 180 мм багатоступеневими низькотемпературними режимами розглянуто графоаналітичний метод П.С. Сєрговського та аналітичні методи William T. Simpson i F. Kollmann. Для умов, проаналізованих у статті, результати обчислення за всіма методами відрізняються від експериментальних більше ніж на $20 \%$.

Порівняння трьох аналітичних методів F. Kollmann, L. Vorreiter та William T. Simpson у роботі (Fortuin, 2003) виявило, що всі методи визначення тривалості сушіння дають результати, які значно відрізняються між собою. За однакових умов процесу сушіння найменшу тривалість процесу отримано методом F. Kollmann, а найбільшу - методом William T. Simpson.

Отже, актуальним напрямом досліджень є аналіз методів визначення тривалості сушіння пиломатеріалів з використанням сучасних режимів сушіння у конвективних камерах періодичної дії.

На тривалість процесу конвективного сушіння пиломатеріалів впливає низка чинників: 3 якої деревної породи виготовлено матеріал, його розміри, початкова і кінцева вологість, режим сушіння (температура та відносна вологість агента сушіння), а також швидкість руху агента сушіння через штабель висушуваного матеріалу (Andreeva, \& Petrovskaya, 1970; Huber, 2003; Biley, 2005; Huber \& Kopynets, 2009; Biley et al., 2010). Тому дослідження здійснено для окремого випадку з постійними значеннями наведених вище параметрів.
Об'єкти та методика дослідження. Об'єкт дослідження - процес сушіння необрізних соснових пиломатеріалів завтовшки 30 мм у конвективній сушильній камері періодичної дії. Предмет дослідження - тривалість сушіння соснових необрізних пиломатеріалів у конвективній сушильній камері періодичної дії. Метою роботи є встановлення максимально точного способу визначення тривалості сушіння за відповідних умов проведення процесу.

Для досягнення поставленої мети здійснено низку експериментальних досліджень у виробничих умовах, за результатами яких встановлено тривалість сушіння соснових необрізних пиломатеріалів багатоступеневим режимом сушіння у конвективній сушильній камері періодичної дії фірми LeKo типу LK-ZDR-50 з об'ємом завантаження близько $50 \mathrm{~m}^{3}$ пиломатеріалів.

У процесі досліджень висушували соснові необрізні пиломатеріали завтовшки 30 мм та завдовжки $3 . . .3,2$ м. У сушильну камеру завантажували пиломатеріали з початковою вологістю $\mathrm{W}_{\text {п }} \approx 45 \%$. Кінцева вологість становила $\mathrm{W}_{\mathrm{\kappa}} \approx 9 \%$.

Температура агента сушіння (вологого повітря) на першому ступені режиму становила $\mathrm{t}_{\mathrm{c}}=52^{\circ} \mathrm{C}$, його відносна вологість $-\varphi=73,5 \%$ (рівноважна вологість деревини за цих параметрів $-\mathrm{W}_{\mathrm{p}}=12 \%$ ); на останньому ступені $-\mathrm{t}_{\mathrm{c}}=68^{\circ} \mathrm{C}, \varphi=32,5 \%$ $\left(\mathrm{W}_{\mathrm{p}}=5 \%\right)$. Зміну параметрів процесу здійснювали за середньоарифметичним значенням вологості п'яти контрольних пиломатеріалів впродовж усього процесу сушіння.

Циркуляція агента сушіння в камері-поперечновертикальна. Середня швидкість його руху через штабель висушуваного матеріалу, виміряна 3 використанням крильчастого анемометра 3 телескопічним зондом Testo 416, за вологості висушуваних пиломатеріалів більше $31 \%$ становила $v=2,5 \mathrm{~m} / \mathrm{c}$, за вологості менше $31 \%-v=1,5 \mathrm{~m} / \mathrm{c}$.

Для порівняння, щоб визначити тривалість сушіння соснових пиломатеріалів, проаналізовано одинадцять відомих методів.

Тривалість сушіння пиломатеріалів та заготовок, що враховує тривалість початкового прогрівання і тепловологообробок визначають за формулою (Biley et al., 2010; Sergovskiy, \& Rasev, 1987):

$$
\tau_{\mathrm{c}}=\tau_{\text {вих }} \cdot \mathrm{A}_{\mathrm{p}} \cdot \mathrm{A}_{\text {и }} \cdot \mathrm{A}_{\text {в }} \cdot \mathrm{A}_{\text {я }} \cdot \mathrm{A}_{\text {д }} \text { год, }
$$

де $\tau_{\text {вих }}-$ вихідна тривалість сушіння пиломатеріалів заданої породи і розмірів нормальним режимом від початкової вологості $60 \%$ до кінцевої $12 \%$ в камерах з реверсивною циркуляцією агента сушіння середньої інтенсивності з розрахунковою його швидкістю через штабель висушуваного матеріалу $1 \mathrm{~m} / \mathrm{c}$, год; $\mathrm{A}_{\mathrm{p}}, \mathrm{A}_{\mathrm{u}}, \mathrm{A}_{\mathrm{z}}, \mathrm{A}_{\mathrm{s}}, \mathrm{A}_{\text {д }}$ в відповідно коефіцієнти, які враховують категорію режиму сушіння, інтенсивність циркуляції агента сушіння, початкову та кінцеву вологість деревини, якість висушуваного матеріалу і його довжину. 
Цей метод відомий під назвою «табличний», оскільки для визначення компонентів, які входять у формулу (1), використовують таблиці і він рекомендований до застосування «Керівними технічними матеріалами 3 технології камерного сушіння пиломатеріалів» (Biley et al., 2010). Оскільки його розроблено для розрахунку тривалості сушіння із застосуванням триступеневих режимів згідно 3 Sergovskiy \& Rasev (1987), то за умови використання інших режимів, він дає значні відхилення, тому здійснюють роботи з його адаптації для сучасних режимів (Snopkov, \& Babich, 2008; Pinchevska, Koval, Buyskih, Spirochkin, \& Kompanets, 2012).

У роботі Snopkov, \& Babich (2008) запропоновано уточнення коефіцієнта категорії режиму сушіння у формулі (1) з урахуванням градієнта сушіння на кожному ступені режиму й отримано експоненціальну залежність для його визначення:

$$
A_{p}=4,5641 \cdot e^{-0,3206 \cdot G_{\mathrm{c} 3}}
$$

де $\mathrm{G}_{\mathrm{c} 3}$ - середньозважений градієнт сушіння.

$$
\mathrm{G}_{\mathrm{c} 3}=\frac{\sum\left(\frac{\mathrm{W}_{\mathrm{ni}}+\mathrm{W}_{\mathrm{ki}}}{2 \cdot \mathrm{W}_{\mathrm{pi}}} \cdot\left(\mathrm{W}_{\mathrm{ni}}-\mathrm{W}_{\mathrm{ki}}\right)\right)}{\mathrm{W}_{\mathrm{n}}-\mathrm{W}_{\mathrm{k}}},
$$

де $\mathrm{W}_{\text {пі, }}, \mathrm{W}_{\text {кі }}, \mathrm{W}_{\text {pi }}$ - відповідно початкова, кінцева $\mathrm{i}$ рівноважна вологість деревини на кожному із ступенів режиму сушіння; $\mathrm{W}_{\text {п }}, \mathrm{W}_{\mathrm{\kappa}}$ - відповідно початкова і кінцева вологість пиломатеріалів на початку і в кінці процесу сушіння.

У деяких роботах (Pinchevska et al., 2012; Spirochkin, 2013) у формулу (1) введено коефіцієнт $\mathrm{A}_{\text {н.р. }}$, який враховує нерівномірність розподілення аеродинамічного поля у сушильній камері та дисперсію початкової вологості у партії пиломатеріалів. Тоді формула (1) набуває вигляду:

$$
\tau_{\mathrm{c}}=\tau_{\text {вих }} \cdot \mathrm{A}_{\mathrm{p}} \cdot \mathrm{A}_{\text {щ }} \cdot \mathrm{A}_{\mathrm{в}} \cdot \mathrm{A}_{\text {я }} \cdot \mathrm{A}_{\text {д }} \cdot \mathrm{A}_{\text {н.р, }} \text {, год, }
$$

Додатково у згаданих дослідженнях встановлено, що коефіцієнт, який враховує категорію режиму для сучасних низькотемпературних режимів сушіння, становить $A_{p}=2,5$.

Andrashek (2011) пропонує визначати тривалість сушіння пилопродукції без урахування тривалості початкового прогрівання і тепловологообробок за формулою:

$$
\tau_{\mathrm{c}}=\tau_{\text {вих }} \cdot \mathrm{A}_{\text {пा }} \cdot \mathrm{A}_{\mathrm{t}_{1}} \cdot \mathrm{A}_{\mathrm{t}_{2}} \cdot \mathrm{A}_{\text {к.с }} \cdot \mathrm{A}_{v} \cdot \mathrm{A}_{\mathrm{B}, \mathrm{n}} \cdot \mathrm{A}_{\mathrm{\kappa} . \mathrm{B}}, \text { год, }
$$

де $\tau_{\text {вих }}$ - вихідна тривалість сушіння хвойних пиломатеріалів заданої товщини від певної початкової вологості до кінцевої вологості 8\% за початкової температури сушильного агента $70^{\circ} \mathrm{C}$ і кінцевої температури $80^{\circ} \mathrm{C} ; \mathrm{A}_{\pi}, \mathrm{A}_{\mathrm{t}}, \mathrm{A}_{\mathrm{t}}, \mathrm{A}_{\text {к.с }}, \mathrm{A}_{v}, \mathrm{~A}_{\text {в. } \mathrm{n}}, \mathrm{A}_{\text {к.в }}-$ відповідно коефіцієнти, які враховують породу пиломатеріалів; відхилення початкової температури вибраного режиму сушіння від початкової температури, що становить $70^{\circ} \mathrm{C}$; відхилення кінцевої температури вибраного режиму сушіння від кінцевої температури, що становить $80^{\circ} \mathrm{C}$; категорію ре- жиму сушіння; швидкість циркуляції агента сушіння через штабель висушуваного матеріалу; вид пилопродукції (обрізна, необрізна дошка, заготовка); значення кінцевої вологості висушуваного матеріалу.

Орієнтовну тривалість сушіння без урахування початкового нагрівання та вологотеплообробок Glijer (2011) пропонує визначати за залежністю:

$$
\tau_{\mathrm{c}}=\tau_{\text {вих }} \cdot \mathrm{k}_{1} \cdot \mathrm{k}_{2} \cdot \mathrm{k}_{3} \cdot \mathrm{k}_{4} \cdot \mathrm{k}_{5} \cdot \mathrm{k}_{6} \text {, год, }
$$

де $\tau_{\text {вих }}$ - вихідна тривалість сушіння хвойних пиломатеріалів заданої товщини від певної початкової вологості до кінцевої вологості 8\% за початкової температури агента сушіння $80^{\circ} \mathrm{C}$ і кінцевої його температури $90^{\circ} \mathrm{C} ; \mathrm{k}_{1}, \mathrm{k}_{2}, \mathrm{k}_{3}, \mathrm{k}_{4}, \mathrm{k}_{5}, \mathrm{k}_{6}$, - відповідно коефіцієнти, які враховують породу пиломатеріалів; категорію режиму; відхилення початкової температури вибраного режиму сушіння від початкової температури визначення вихідної тривалості, що становить $80^{\circ} \mathrm{C}$; швидкість циркуляції агента сушіння через штабель висушуваного матеріалу; вид пилопродукції (обрізна, необрізна дошка, заготовка); реверсивність циркуляції.

Графоаналітичний метод П. С. Сєрговського полягає у визначенні тривалості низькотемпературного процесу сушіння на кожному ступені режиму без урахування початкового нагрівання та вологотеплообробок (Sergovskiy, \& Rasev, 1987):

$$
\begin{aligned}
& \tau_{1}=C_{\tau 1} \cdot \frac{\mathrm{K} \cdot \mathrm{S}_{1}^{2}}{\mathrm{a}_{\mathrm{M} 1}^{\prime} \cdot 10^{6}} \cdot \mathrm{C}_{1} \cdot \mathrm{A}_{\mathrm{L}} \cdot \lg \left(0,81 \cdot \frac{\mathrm{W}_{\mathrm{m} 1}-\mathrm{W}_{\mathrm{p} 1}}{\mathrm{~W}_{\mathrm{k} 1}-\mathrm{W}_{\mathrm{p} 1}}\right), \\
& \tau_{2 \ldots \mathrm{n}}=\mathrm{C}_{\tau 2 \ldots \mathrm{i}} \cdot \frac{\mathrm{K} \cdot \mathrm{S}_{1}^{2}}{\mathrm{a}_{\mathrm{M} 2 \ldots \mathrm{i}}^{\prime} \cdot 10^{6}} \cdot \mathrm{C}_{2 \ldots \mathrm{i}} \cdot \mathrm{A}_{\mathrm{u}} \cdot \lg \left(\frac{\mathrm{W}_{\mathrm{n} 2 \ldots \mathrm{i}}-\mathrm{W}_{\mathrm{p} 2 \ldots \mathrm{i}}}{\mathrm{W}_{\mathrm{k} 2 \ldots \mathrm{i}}-\mathrm{W}_{\mathrm{p} 2 \ldots \mathrm{i}}}\right),
\end{aligned}
$$

де $\mathrm{C}_{t i}$ - поправка на багатомірність, що враховує ширину пиломатеріалів (визначають за графіком залежно від безрозмірної вологості $\Theta_{1 \ldots . \mathrm{i}}=\frac{\mathrm{W}_{\mathrm{k} 1 . . \mathrm{i}}-\mathrm{W}_{\mathrm{p} 1 . \mathrm{i}}}{\mathrm{W}_{\mathrm{ml} . \mathrm{i}}-\mathrm{W}_{\mathrm{p} 1 \ldots \mathrm{i}}}$ і відношення товщини до ширини пиломатеріалу $\frac{\mathrm{S}_{1}}{\mathrm{~S}_{2}}$ на кожному ступені режиму сушіння; $\mathrm{K}$ - множник, який враховує співвідношення одиниць вимірювання; $\mathrm{S}_{1}$ - товщина пиломатеріалів, см; $\mathrm{C}_{\mathrm{i}}-$ коефіцієнт, який враховує сповільнення процесу сушіння у штабелі різної ширини (визначають для кожного ступеня); $\mathrm{A}_{u}$ - коефіцієнт, який враховує реверсивність циркуляції; $\mathrm{a}_{\mathrm{Mi}}^{\prime}-$ коефіцієнт вологопровідності деревини за температури змоченого термометра на кожному із ступенів режиму сушін$\mathrm{Hя}, \mathrm{CM}^{2} / \mathrm{c}$.

Для визначення тривалості сушіння як окремих пиломатеріалів, так і пиломатеріалів, вкладених у штабель на прокладки завтовшки $22 . .25$ мм за поперечної рівномірної циркуляції агента сушіння (вологого повітря, водяної пари, топкових газів) за температури вищої як $40^{\circ} \mathrm{C}$, Е. А. Мікіт запропонував залежність (Mikit, 1968): 


$$
\begin{gathered}
\tau=(1+\mathrm{a}) \cdot \mathrm{K}_{\text {п }} \cdot \mathrm{C}_{\text {шт }} \cdot \mathrm{A}_{\text {ц }} \cdot \mathrm{K}_{\mathrm{s}_{1}} \cdot \mathrm{S}_{1}^{1+\mathrm{n}} \cdot \mathrm{K}_{\mathrm{S}_{2} / \mathrm{S}_{1}} \cdot \\
\cdot \frac{\mathrm{A}}{\mathrm{B}} \cdot \ln \frac{\mathrm{W}_{\text {пі }}-\mathrm{W}_{\mathrm{pi}}}{\mathrm{W}_{\text {кі }}-\mathrm{W}_{\mathrm{pi}}}, \text { год, }
\end{gathered}
$$

де а - коефіцієнт, який враховує сушіння пиломатеріалів, вкладених у штабель; К єнт, який враховує породу деревини; $\mathrm{C}_{\text {шт }}-$ коефіці$\epsilon н т$, який враховує ширину штабеля; $\mathrm{A}_{\text {ш }}$ - коефіцієнт, який враховує реверсивність циркуляції агента сушіння через штабель висушуваного матеріалу (за реверсивної циркуляції $\left.\mathrm{A}_{ц}=1,0\right) ; \mathrm{K}_{\mathrm{s}_{1}}$ - коефіцієнт, який враховує товщину пиломатеріалів, вкладених у штабель; n - величина, яка залежить від поточної і рівноважної вологості деревини; $\mathrm{K}_{\mathrm{s}_{1} / \mathrm{s}_{2}}$ коефіцієнт, який враховує відношення ширини пиломатеріалів, до їх товщини (для необрізних дощок $\left.\mathrm{K}_{\mathrm{s}_{1} / \mathrm{s}_{2}}=1,0\right) ; \mathrm{A}-$ коефіцієнт, який враховує температуру і відносну вологість агента сушіння; В - коефіцієнт, який враховує швидкість циркуляції агента сушіння.

Цей метод також можна назвати графоаналітичним, оскільки низку компонентів, які входять у формулу (9), визначають за відповідними графіками (Mikit, 1968).

Рівняння тривалості сушіння за методом F. Kollmann (Brunner-Hildebrand. Die schnittholztrocknung. 5 auflage, 1987, Fortuin, 2003) має вигляд:

$$
\tau_{\mathrm{c}}=\frac{1}{\alpha_{\mathrm{T}}} \cdot \ln \frac{\mathrm{W}_{\text {пі }}}{\mathrm{W}_{\mathrm{ki}}} \cdot\left(\frac{\mathrm{S}_{1}}{25}\right)^{1,5} \cdot\left(\frac{65}{\mathrm{t}_{\mathrm{c}}}\right) \cdot\left(\frac{\rho_{0}}{\rho_{0 \alpha}}\right)^{1,5} \text {, год, }
$$

де $\alpha_{\mathrm{T}}-$ коригувальний коефіцієнт, який залежить від породи деревини і початкової вологості висушуваного матеріалу, конструктивних особливостей камери, відносної вологості агента сушіння й інших чинників: $\alpha_{\mathrm{T}}=0,0477$ - для хвойних порід деревини густиною в абсолютно сухому стані $\rho_{0}=0,45 \mathrm{\Gamma} / \mathrm{cm}^{3}$, $\alpha_{\mathrm{T}}=0,0265$ - для листяних порід деревини густиною в абсолютно сухому стані $\rho_{0}=0,65 \Gamma / \mathrm{cm}^{3}$; $\mathrm{t}_{\mathrm{c}}$ - температура агента сушіння, ${ }^{\circ} \mathrm{C}$.

Аналітичний метод William T. Simpson полягає у поступеневому визначенні тривалості сушіння пиломатеріалів за виразом (Simpson, 1996):

$$
\tau_{1 \ldots \mathrm{n}}=\frac{-\mathrm{S}_{1}^{1,52}}{\mathrm{~b}_{\mathrm{s}}} \cdot \frac{\mathrm{b}_{\mathrm{T}_{1}}}{\mathrm{~b}_{\mathrm{T}_{2}}} \cdot \ln \left(\frac{\mathrm{W}_{\mathrm{\kappa} 1 \ldots \mathrm{i}}-\mathrm{W}_{\mathrm{p} 1 \ldots \mathrm{i}}}{\mathrm{W}_{\mathrm{m} 1 \ldots \mathrm{i}}-\mathrm{W}_{\mathrm{p} 1 \ldots \mathrm{i}}}\right) \text {, діб, }
$$

де $b_{\mathrm{s}}$ - емпіричний коефіцієнт, який враховує умовну густину деревини; $\mathrm{b}_{\mathrm{T}_{1}}-$ емпіричний коефіцієнт для температури $49^{\circ} \mathrm{C} ; \mathrm{b}_{\mathrm{T}_{2}}-$ емпіричний коефіцієнт для температур у межах $38 \ldots 82^{\circ} \mathrm{C}$.

Для визначення тривалості сушіння за вологості понад 30\% та менше 30\% Т. Trübswetter (2009) наводить формули:

$$
\tau_{\mathrm{cl}}=\ln \frac{\mathrm{W}_{\text {пі }}}{\mathrm{W}_{\text {кі }}} \cdot\left(\frac{\mathrm{S}_{1}}{25}\right)^{\mathrm{n}} \cdot \mathrm{f}_{\phi} \cdot \mathrm{f}_{\text {п }} \cdot\left(\frac{150-\mathrm{t}_{\mathrm{c}}}{\mathrm{t}_{\mathrm{c}}}\right)^{1,5} \cdot \mathrm{f}_{\text {рк }}, \text { гОД, }
$$

$$
\tau_{\text {с } 2}=\ln \frac{\mathrm{W}_{\text {пі }}}{\mathrm{W}_{\text {кі }}} \cdot\left(\frac{\mathrm{S}_{1}}{25}\right)^{\mathrm{n}} \cdot \mathrm{f}_{\phi} \cdot \mathrm{f}_{\text {п }} \cdot\left(\frac{150-\mathrm{t}_{\mathrm{c}}}{\mathrm{t}_{\mathrm{c}}}\right)^{1,5} \cdot \frac{3,0}{\mathrm{TG}} \cdot \mathrm{f}_{\text {рк }}, \text { ГОД, }
$$

де $\mathrm{f}_{\phi}, \mathrm{f}_{n}, \mathrm{f}_{\mathrm{pк}}-$ відповідно коефіцієнти, які враховують вид обробки пиломатеріалів, породу та режим роботи камери; TG - градієнт сушіння.

Vorreiter (1958) запропонував визначати поступеневу тривалість сушіння за залежністю:

$$
\tau_{\mathrm{c}}=\ln \frac{\mathrm{W}_{\text {пі }}}{\mathrm{W}_{\text {кі }}} \cdot \frac{\mathrm{R}_{0} \cdot \mathrm{S}_{1}^{2}}{\mathrm{v}^{0,6} \cdot\left(\frac{\mathrm{t}_{\mathrm{c}}}{100}\right)^{3,4} \cdot 0,03 \cdot \sin \left(\frac{\pi}{2} \cdot \frac{\rho_{0}}{\rho_{\text {дер.реч }}}\right)}, \text { гоД, }(1
$$

де $\mathrm{R}_{0}$ - густина деревини в абсолютно сухому стані, кг $/ \mathrm{M}^{3} ; \rho_{0}-$ густина деревини в абсолютно су-

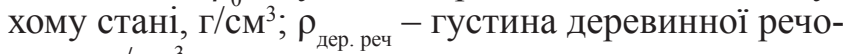
вини, г/ $\mathrm{cm}^{3}$.

Результати та обговорення. Внаслідок оброблення та аналізу десяти протоколів спостережень процесів сушіння соснових необрізних пиломатеріалів у конвективній сушильній камері періодичної дії фірми LeKo типу LK-ZDR-50 отримано експериментальні криві сушіння та виконано розрахунки тривалості сушіння за досліджуваних умов наведеними методами.

Як відомо (Huber, 2003), процес сушіння можна проводити за вологістю найвологішого зразка (зазвичай, на початку процесу сушіння), або за середньою вологістю пиломатеріалів, в яких встановлено давачі вологості (зазвичай, наприкінці процесу сушіння). Процес сушіння у цьому дослідженні здійснено за середньою вологістю п'яти контрольних пиломатеріалів, в яких встановлено давачі вологості.

Наведені на рис. 1 графіки відображають криві сушіння окремих досліджуваних процесів (без нагрівання, початкової вологотеплообробки, кондиціонування та охолодження).

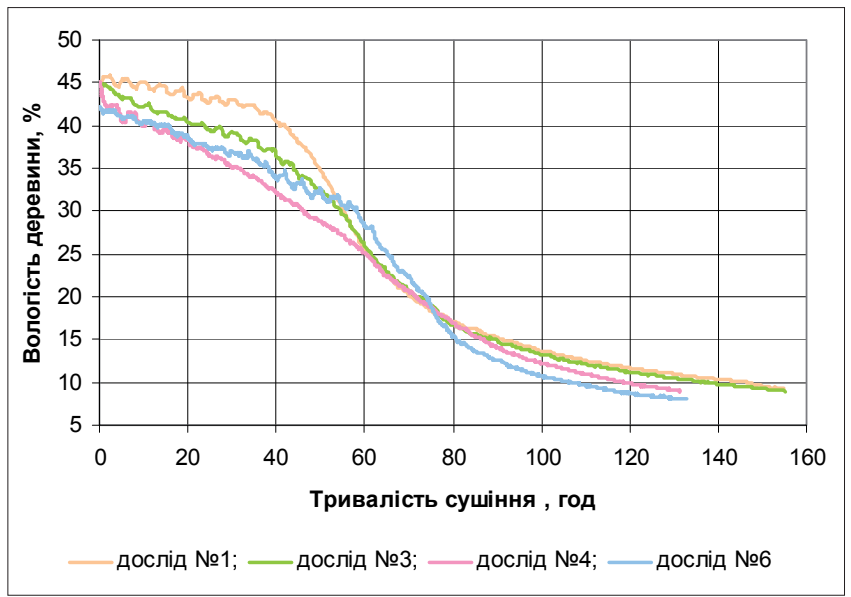

Рис. 1. Криві сушіння соснових необрізних пиломатеріалів завтовшки 30 мм

Тривалість сушіння соснових необрізних пиломатеріалів завтовшки 30 мм у конвективній сушильній камері періодичної дії фірми LeKo типу 
LK-ZDR-50 від середньої початкової вологості $\mathrm{W}_{\text {п }} \approx 45 \%$ до кінцевої $\mathrm{W}_{\mathrm{\kappa}} \approx 9 \%$ становила від $\tau=131,2$ год до $\tau=155,3$ год. Середне значення тривалості десяти дослідних процесів сушіння становить $\tau=146,28$ год. Результати розрахунків за наведеними методами подано у табл.

Порівняння результатів розрахунків тривалості сушіння за табличним методом і за результатами експерименту у сушильній камері фірми LeKo по- казує значну розбіжність. Цей метод дає занижені результати - розрахована тривалість сушіння менша на 28,23\% від експериментальної.

Удосконалення цього методу за рахунок уточнення коефіцієнта, який враховує категорію та жорсткість режиму сушіння через величину градієнта сушіння, не дає потрібних результатів для заданих умов дослідження. Тривалість сушіння є меншою на $34,72 \%$, ніж експериментальна.

Таблиия

\section{Результати розрахунків тривалості сушіння соснових необрізних пиломатеріалів завтовшки 30 мм у конвективній сушильній камері періодичної дії}

\begin{tabular}{|c|c|c|c|c|}
\hline$\stackrel{F}{\stackrel{F}{\dddot{m}}}$ & Метод & $\begin{array}{l}\text { Номер } \\
\text { формули }\end{array}$ & $\begin{array}{l}\text { Тривалість, } \\
\text { год }\end{array}$ & $\begin{array}{c}\text { Відхилення від } \\
\text { експериментального, \% }\end{array}$ \\
\hline 1 & $\begin{array}{l}\text { Табличний згідно з «Керівними технічними } \\
\text { матеріалами з технології камерного сушіння } \\
\text { пиломатеріалів» }\end{array}$ & (1) & 105 & $-28,23$ \\
\hline 2 & Табличний (з уточненням A $)$ & $(1),(2),(3)$ & 95,5 & $-34,72$ \\
\hline 3 & Табличний (з уточненням $\mathrm{A}_{\mathrm{p}}$ та введенням $\mathrm{A}_{\text {н.р }}$ ) & (4) & 211,7 & $+44,70$ \\
\hline 4 & Табличний Й. В. Андрашека & (5) & 199,8 & $+36,57$ \\
\hline 5 & Табличний L. Glijer & (6) & 86,0 & $-41,22$ \\
\hline 6 & Графоаналітичний П. С. Серговського & $(7),(8)$ & 142,9 & $-2,32$ \\
\hline 7 & Графоаналітичний Е.А. Мікіта & (9) & 84,9 & $-41,97$ \\
\hline 8 & Аналітичний F. Kollmann & (10) & 30,1 & $-79,43$ \\
\hline 9 & Аналітичний William T. Simpson & (11) & 135,7 & $-7,25$ \\
\hline 10 & Аналітичний згідно з Т. Trübswetter & $(12),(13)$ & 89,7 & $-38,69$ \\
\hline 11 & Аналітичний L. Vorreiter & (14) & 142,7 & $-2,46$ \\
\hline
\end{tabular}

Зіставлення результатів експериментальних досліджень і розрахунків згідно з табличним методом із використанням коефіцієнта, який враховує нерівномірність розподілення аеродинамічного поля у сушильній камері та дисперсію початкової вологості в партії пиломатеріалів, показало перевищення розрахункових даних на 44,70\%. Цей метод розроблено на підставі експериментальних досліджень у сушильних камерах «Termolegno», «Copcal» та «Nardi», особливістю технологічних процесів в яких $\epsilon$ порівняно м'які режими. Використання цього методу вимагає додаткових експериментальних досліджень розподілення аеродинамічного поля у сушильній камері, а отже, $є$ незручним у реальних умовах.

Для заданих умов дослідження результат обчислення тривалості сушіння за табличним методом Й.В. Андрашека $є$ завищеним на $36,57 \%$, а табличним методом L. Glijer - заниженим на 41,22\%. Тому в обох випадках доцільно здійснити додаткові дослідження з уточнення вихідної тривалості сушіння. У табличному методі L. Glijer не враховано кінцеву вологість висушуваних пиломатеріалів.

Графоаналітичний метод Е.А. Мікіта $є$ громіздким для розрахунків, навіть 3 використанням комп'ютерної техніки. Кожен коефіцієнт у форму- лі (9) потрібно знаходити як середне 3 двох величин - на початку і наприкінці кожного ступеня, що під час застосування графіків займає багато часу. Точність визначення коефіцієнтів за графіками суттєво впливає на результат. Тривалість сушіння, обчислена за цим методом, на 41,97\% менша від отриманої експериментально.

Згідно 3 розрахунками за аналітичним методом F. Kollmann, тривалість сушіння соснових необрізних пиломатеріалів на 79,43\% менша, порівняно з результатами експерименту. У формулу (10) входить коригувальний коефіцієнт, який залежить від породи деревини і початкової вологості висушуваного матеріалу, конструктивних особливостей камери, відносної вологості агента сушіння та інших чинників, зокрема, відповідно до (BrunnerHildebrand. Die schnittholztrocknung. 5 auflage, 1987) $\alpha_{\mathrm{T}}=0,0477$ для хвойних порід деревини. Відкритим $€$ питання, для яких саме конструкцій сушильних камер, початкової вологості деревини, відносної вологості агента сушіння встановлено цей коефіцієнт. Результати розрахунків за запропонованою методикою засвідчили, що для умов цього дослідження він повинен становити $\alpha_{\mathrm{T}}=0,0098$.

За результатами розрахунку згідно 3 аналітичним методом T. Trübswetter виявлено значне від- 
хилення в бік зменшення - на 38,69\% порівняно 3 отриманими експериментальними даними. Аналіз формул (12) та (13) дав змогу встановити, що якщо у них замінити $\ln \frac{\mathrm{W}_{\text {пi }}}{\mathrm{W}_{\text {кі }}}$ на $\ln \frac{\mathrm{W}_{\text {пi }}-\mathrm{W}_{\mathrm{pi}}}{\mathrm{W}_{\mathrm{ki}}-\mathrm{W}_{\mathrm{pi}}}$, отримаємо тривалість сушіння 136,7 год, яка є меншою від експериментального значення на 7,82\%.

Близькі до експериментальних результати розрахунків тривалості сушіння за досліджуваних умов отримано з використанням графоаналітичного методу П.С. Сєрговського (відхилення в бік зменшення становить 2,32\%), аналітичного методу William T. Simpson (відхилення в бік зменшення становить $7,25 \%$ ) та аналітичного методу L. Vorreiter (відхилення в бік зменшення становить 2,46\%).

Побудовані криві сушіння за результатами розрахунків згідно з методами, які дають змогу поступеневого обчислення тривалості сушіння, наведено на рис. 2.

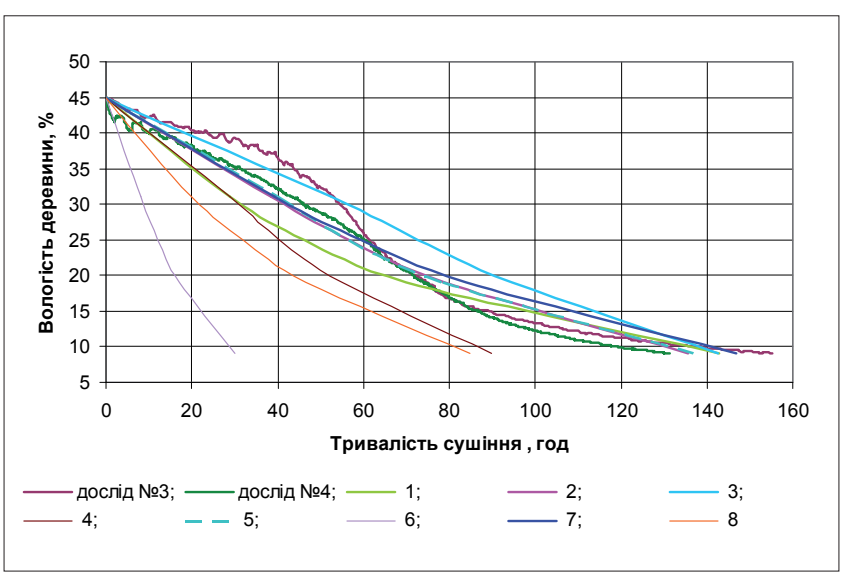

Рис. 2. Експериментальні та розрахункові криві сушіння: 1 - графоаналітичний П. С. Серговського; 2 - аналітичний William T. Simpson; 3 - аналітичний

L. Vorreiter; 4 - аналітичний F. Kollmann;

5 - аналітичний F. Kollmann за $\alpha_{\mathrm{T}}=0,0098$; 6 - аналітичний згідно з Т. Trübswetter; 7 - аналітичний згідно з T. Trübswetter з урахуванням запропонованого удосконалення; 8 - графоаналітичний Е. А. Мікіта

Висновки. Для визначення тривалості сушіння соснових необрізних пиломатеріалів у сучасних конвективних сушильних камерах періодичної дії можна рекомендувати такі методи: графоаналітичний П. С. Сєрговського, аналітичний William T. Simpson та аналітичний L. Vorreiter.

Для заданих умов дослідження за використання методу F. Kollmann коригувальний коефіцієнт, який залежить від породи деревини і початкової вологості висушуваних пиломатеріалів, конструкції камери, відносної вологості агента сушіння, повинен становити $\alpha_{\mathrm{T}}=0,0098$. Однак, за зміни чинників, від яких залежить цей коефіцієнт, результати розрахунків можуть значно відрізнятися від експериментальних даних.

За методом згідно $3 \mathrm{~T}$. Trübswetter результати розрахунків дають достатню точність за умови за- міни відношення $\ln \frac{\mathrm{W}_{\text {пi }}}{\mathrm{W}_{\text {кі }}}$ у формулах (12), (13) на $\ln \frac{\mathrm{W}_{\text {пі }}-\mathrm{W}_{\mathrm{pi}}}{\mathrm{W}_{\text {кi }}-\mathrm{W}_{\mathrm{pi}}}$.

\section{References}

Andrashek, Y.V. (2011). Methodical instructions for implementation of the academic year project in the discipline "Technology of drying and protection of wood». Lviv: Ukrainian National Forestry University (in Ukrainian).

Andreeva, A.A., \& Petrovskaya, A.A. (1970). Comparative evaluation of methods for calculating the duration of chamber drying of lumber. Woodworking industry, 11, 12-14. Retrieved from https://www. booksite.ru/derevo/1970/1970_11.pdf(in Russian).

Biley, P.V., Sokolovsky, I.A., Pavliust V.M., \& Kynunets, E. P. (2010). Guiding technical materials on the chamber drying technology of sawn timber. Uzhgorod: Carpathians (in Ukrainian).

Biley, P.V. (2005). Theoretical foundations of heat treatment and drying of wood. Kolomyia: Vik (in Ukrainian).

Brunner-Hildebrand. Die schnittholztrocknung. 5 auflage. (1987). Hannover: Buchdruckwerkstatten Hannover $\mathrm{GmbH}$.

Fortuin, G. (2003). Anwendung mathematischer Modelle zur Beschreibung der technischen Konvektionstrocknung von Schnittholz (Dissertation zur Eriangung des Doktorgrades an der Universität Hamburg, Hamburg, Douchlend). Retrieved from https://d-nb.info/969246366/34.

Glijer, L. (2011). Drying wood and more. Warszawa: Wies Jutra.

Huber, Yu. M., \& Kopynets, Z.P. (2009) Analysis methods determination duration of drying thin sawtimbers. Scientific Bulletin of Ukrainian National Forestry University, 19.2, 100-104. Retrieved from https://nv.nltu.edu.ua/Archive/2009/19_2/index.htm. (in Ukrainian).

Huber, Yu. (2003). Recommendations on lumber drying schedule in convective dryers. Lviv: Ukrainian State Forestry University (in Ukrainian).

Mikit, E.A. (1968). Method for determining the drying time of lumber, plywood veneer, wood shavings and sawdust. Riga: LRINTIP (in Russian).

Pinchevska, O.O., Koval, V.S., Buyskih, N.V., Spirochkin, A.K., \& Kompanets, S.M. (2012). Technological regulation of the process of drying lowgrade wood. Kharkiv: CenterInform (in Ukrainian).

Sergovskiy, P. S., \& Rasev, A. I. (1987). Hydrothermal treatment and preservation of wood. Moscow: Forest industry. Retrieved from https://www.studmed. $\mathrm{ru} /$ sergovskiy-ps-rasev-ai-gidrotermicheskayaobrabotka-i-konservirovanie-drevesiny_cea1f72 46b0.html (in Russian).

Simpson, W.T. (1996). Method to Estimate DryKiln Schedules and Species Groupings. Tropical 
and Temperate Hardwoods. Madison, WI: U.S. Department of Agriculture, Forest Service, Forest Products Laboratory.

Snopkov, V.B., \& Babich, D.P. (2008). Calculation of the duration of drying sawn-timber in non-standard modes. Proceedings of Belarusian State Technical University: Timber and woodworking industry, 2, 174178. Retrieved from https://cyberleninka.ru/article/n/ raschet-prodolzhitelnosti-sushki-pilomaterialovnestandartnymi-rezhimami (in Russian).

Spirochkin, A.K. (2013). Approbation of pine timber drying duration determination method. The bulletin of the Kharkiv State National Technical University of Agriculture of the name of P. Vasilenko, 136, 36-43. Retrieved from http://www.irbis-nbuv. gov.ua/cgi-bin/irbis nbuv/cgiirbis 64.exe?I21D $\mathrm{BN}=\mathrm{LINK} \& \mathrm{P} 21 \mathrm{DB} \overline{\mathrm{N}}=\mathrm{UJRN} \& \mathrm{Z} 2 \overline{1} \mathrm{ID}=\& \mathrm{~S} 21 \mathrm{RE}$ $\mathrm{F}=10 \& \mathrm{~S} 21 \mathrm{CNR}=20 \& \mathrm{~S} 21 \mathrm{STN}=1 \& \mathrm{~S} 21 \mathrm{FMT}=\mathrm{A}$ $\mathrm{SP}$ meta\&C21COM=S\&2 S21 P03 $=$ FILA $=\& 2$ S21STR=Vkhdtusg_2013_136_8 (in Ukrainian).

Trübswetter, T. (2009). Holzttrocknung. Verfahren zur Trocknung von Schnittholz - Planung von trocknungsanlagen. München: Fachbuchverlag Leipzig im Carl Hanser Verlag.

Vorreiter L. (1958) Holztechnologisches Handbuch. Band II: System Holz-Wasser, Holzttrocknung, Dampfen und Kochen, spanlose Holzverformung. Wien: Verlag Georg Fromme \& Co.

\section{Анализ методов определения продолжительности сушки сосновых необрезных пиломатериалов}

\author{
Ю.М. Губер', 3.П. Копинец², Ю. Р. Дадак³, \\ Ж.Я. Гуменюк ${ }^{4}$
}

Конвективный способ сушки пиломатериалов в камерах периодического действия является наиболее распространенным. Для обеспечения выполнения производственной программы важным аспектом является определение необходимого количества сушильных камер, а в расчете их производительности учитывается продолжительность процесса сушки. Это основной этап как для планирования работы уже существующих сушильных цехов, так и для проектирования новых деревообрабатывающих предприятий, их расширения либо реконструкции.

По результатам исследованных процессов сушки, проводимых в производственных условиях в конвективной сушильной камере периодического действия фирмы LeKo типа LK-ZDR-50 с объемом загрузки пиломатериалов около $50 \mathrm{~m}^{3}$, установлено продолжительность сушки многоступенчатым режимом сосновых необрезных пиломатериалов толщиной 30 мм и длиной $3 \ldots 3,2$ м. В процессе экспериментальных исследований начальная влаж- ность пиломатериалов составила $\mathrm{W}_{\text {п }} \approx 45 \%$, конечная $-\mathrm{W}_{\mathrm{\kappa}} \approx 9 \%$. Температура агента сушки (влажного воздуха) на первой ступени режима сушки $-\mathrm{t}_{\mathrm{c}}=52^{\circ} \mathrm{C}$, относительная влажность агента сушки $-\varphi=73,5 \%$; на последней ступени $-\mathrm{t}_{\mathrm{c}}=68^{\circ} \mathrm{C}$, $\varphi=32,5 \%$. Схема циркуляции агента сушки в камеpe - поперечно-вертикальная, средняя скорость его движения в штабеле, измеренная с использованием крыльчатого анемометра с телескопическим зондом Testo 416, при влажности высушиваемых пиломатериалов более $31 \%$ составляла $v=2,5 \mathrm{M} / \mathrm{c}$, при влажности менее $31 \%-v=1,5$ м/с. Среднее значение продолжительности исследуемых процессов сушки составило $\tau=146,28$ часов.

С целью анализа избрано одиннадцать расчетных методов определения продолжительности сушки пиломатериалов, а именно: табличный, рекомендуемый «Руководящими техническими материалами по технологии камерной сушки пиломатериалов» и два его варианта с некоторыми поправками, табличный И.В. Андрашека, табличный L. Glijer, графоаналитический П.С. Серговского, графоаналитический Э.А. Микита, аналитический F. Kollmann, аналитический William T. Simpson, аналитический согласно T. Trübswetter, аналитический L. Vorreiter.

По результатам сравнения проведенных расчетов продолжительности сушки с экспериментальными данными установлено, что для сосновых необрезных пиломатериалов в современных конвективных сушильных камерах периодического действия можно рекомендовать следующие методы: графоаналитический Серговского П.С. отклонение составляет $-2,32 \%$, аналитический William T. Simpson - отклонение составляет -7,25\%

Губер Юрий Мирославович - кандидат технических наук, доцент кафедры технологий защиты окружающей среды и древесины, безопасности жизнедеятельности и социальных коммуникаций. Национальный лесотехнический университет Украины, ул. генерала Чупринки, 103, г. Львов, 79057, Украина. Тел.: +380678117118. E-mail: yuriy.huber@nltu.edu.ua ORCID: http:// orcid.org/0000-0003-2678-511X

Копинец Зоя Павловна - кандидат технических наук, доцент кафедры технологий лесопиления, столярных и деревянных строительных изделий. Национальный лесотехнический университет Украины, ул. генерала Чупринки, 103, г. Львов, 79057, Украина. Тел.: +38-067-670-20-58. E-mail: zoya.kopynets@nltu. edu.ua ORCID: http://orcid.org/0000-0001-8977-6953

3 Дадак Юрий Романович - кандидат технических наук, доцент кафедры технологий лесопиления, столярных и деревянных строительных изделий. Национальный лесотехнический университет Украины, ул. генерала Чупринки, 103, г. Львов, 79057, Украина. Тел.: +38-067-224-42-37. E-mail: yuriy.dadak@nltu. edu.ua ORCID: http://orcid.org/0000-0002-5423-0966

4 Гуменюк Жанна Ярославовна - ассистент кафедры технологий защиты окружающей среды и древесины, безопасности жизнедеятельности и социальных коммуникаций. Национальный лесотехнический университет Украины, ул. генерала Чупринки, 103, г. Львов, 79057, Украи-на. Тел.: +38-097-478-44-07. Е-mail: zhanna.humenyuk@nltu.edu.ua ORCID: http://orcid.org/00000001-9453-5812 
и аналитический L.Vorreiter - отклонение составляет $-2,46 \%$.

Установлено, что для получения достаточно точных в условиях производства результатов, поправочный коэффициент, зависящий от породы древесины, начальной влажности, конструкции камеры, относительной влажности агента сушки по методу F. Kollmann для заданных условий исследований, должен иметь значение $\alpha_{\mathrm{T}}=0,0098$. При изменении условий, от которых он зависит, результаты исчисления по этому методу могут отличаться от экспериментальных данных.

Метод согласно с T. Trübswetter будет достаточно точным для производственных условий (отклонение составит -7,82\%) при условии внесения предложенных в данной работе поправок.

Ключевые слова: параметры режима сушки; температура агента сушки; относительная влажность; скорость движения агента сушки в штабеле; конвективная сушильная камера периодического действия.

\section{Analysis of methods for determining the time to dry unedged pine lumber}

\author{
Yu. Huber' ${ }^{1}$ Z. Kopynets'², Yu. Dadak', \\ Zh. Humeniuk ${ }^{4}$
}

A convective method to dry lumber is the most common in batch kilns. To ensure the implementation of the production plan, it is important to determine the required number of drying chambers, and in the calculation of their productivity, the duration of the drying process is taken into account. This is the main stage both for planning the work of existing drying

Yuriy Huber - PhD in Technical Sciences, Associate Professor of Department of environment and wood protection, safety of life and social communication technologies. Ukrainian National Forestry University, 103, General Chuprynka st., Lviv, 79057, Ukraine. Tel.: +380678117118. E-mail: yuriy.huber@nltu.edu.ua ORCID: http:// orcid.org/0000-0003-2678-511X

2 Zoya Kopynets - PhD in Technical Sciences, Associate Professor of Department of Saw-Milling, Joinery and Wooden Building Products. Ukrainian National Forestry University, 103, General Chuprynka st., Lviv, 79057, Ukraine. Tel.: +38-067-670-2058. E-mail: zoya.kopynets@nltu.edu.ua ORCID: http://orcid. org/0000-0001-8977-6953

Yuriy Dadak - PhD in Technical Sciences, Associate Professor of Department of Saw-Milling, Joinery and Wooden Building Products. Ukrainian National Forestry University, 103, General Chuprynka st., Lviv, 79057, Ukraine. Tel.: +38-067-224-42-37. E-mail: yuriy.dadak@nltu.edu.ua ORCID: http://orcid.org/00000002-5423-0966

4 Zhanna Humeniuk - Assistant Professor of Department of environment and wood protection, safe-ty of life and social communication technologies. Ukrainian National Forestry University, 103, General Chuprynka st., Lviv, 79057, Ukraine. Tel.: +38-097-478-44-07. E-mail: zhan-na.humenyuk@nltu.edu.ua ORCID: http://orcid.org/0000-0001-9453-5812 shops and for designing new woodworking enterprises, their expansion or reconstruction.

According to the results of experimental drying processes carried out under production conditions in a LeKo convective drying batch kiln of the LKZDR-50 type with a loading volume of about $50 \mathrm{~m}^{3}$ of lumber, determined was the drying time for the multistage schedule of drying unedged pine lumber with a thickness of $30 \mathrm{~mm}$ and a length of $3 \ldots 3.2 \mathrm{~m}$. During the experimental studies, the initial moisture content of the lumber was $\mathrm{W}_{\mathrm{n}} \approx 45 \%$, the final $-\mathrm{W}_{\mathrm{\kappa}} \approx 9 \%$. The temperature of the drying agent (moist air) at the first stage of the drying schedule was $t_{c}=52^{\circ} \mathrm{C}$, the relative humidity of the drying agent $-\varphi=73,5 \%$; at the last stage $-t_{c}=68^{\circ} \mathrm{C}, \varphi=32,5 \%$. The circulation scheme of the drying agent in the chamber is transverse-vertical, the average speed of the drying agent movement through the stack, measured using a vane anemometer with a Testo 416 telescopic probe, for moisture content of the lumber being dried is more than $31 \%-v=2,5 \mathrm{~m} / \mathrm{s}$, with moisture content less than $31 \%-v=1,5 \mathrm{~m} / \mathrm{s}$. The average time of the study drying processes is $\tau=146,28 \mathrm{~h}$.

For the purpose of analysis, eleven calculation methods for determining the duration of lumber drying process were selected, namely: tabular, which is recommended by the «Guiding technical materials on the chamber drying technology of sawn timber» and its two variants with certain refinements, tabular by Yo.V. Andrashek, tabular by L. Glijer, graphoanalytical by P.S. Sergovsky, graphoanalytical by E.A. Mikit, analytical by F. Kollmann, analytical by William T. Simpson, analytical according to T. Trübswetter, analytical by L. Vorreiter.

Comparing the calculations results of the time for drying with experimental data, it was found that for unedged pine lumber in modern convective drying batch kilns, the following methods can be recommended: graphoanalytical by P. S. Sergovsky - the deviation is $2.32 \%$, analytical by William T. Simpson - the deviation is $7.25 \%$, and analytical by L. Vorreiter - the deviation is $2.46 \%$.

It was found that in order to obtain results that are sufficiently accurate under production conditions, the correction coefficient, which depends on the wood species, initial moisture content, chamber structure, and relative humidity of the drying agent using the F. Kollmann method, should be $\alpha_{T}=0,0098$ for given research conditions When changing the factors on which it depends, the calculation results by this method can significantly differ from experimental data.

It was found that the method applied according to T. Trübswetter will have sufficient accuracy for production conditions (deviation will be $7.82 \%$ ), subject to the amendments proposed in this paper.

Key words: drying schedule parameters; drying agent temperature; relative humidity; drying agent moving speed through the stack; convective drying batch kiln. 